\title{
Labour pledges to raise NHS wages in line with inflation
}

\author{
David Payne
}

The BMJ

Labour's shadow health secretary, Andy Burnham, has committed to make no real terms cuts in NHS pay under a future Labour government-a pledge that the health secretary for England, Jeremy Hunt, and the Liberal Democrat health minister Norman Lamb refused to match.

The politicians were put on the spot by the BMA's chair of council, Mark Porter, at a debate on health and social care in London this week attended by representatives of the four main UK parties, including the UK Independence Party (UKIP). Porter urged them to value staff, whom he described as the "beating heart of the NHS," and to commit to a real terms pay increase. He said that clinicians had borne the brunt of austerity and efficiency savings imposed by the coalition government since 2010. "The austerity drive and radical efficiency savings were paid for by the workforce. How do you value staff that are the beating heart of the NHS?" asked Porter.

Hunt said, "I can't make that commitment now. Pay has been the single most difficult decision I've had to make as health secretary. I would pay staff as generously providing it doesn't mean laying off nurses - this is what happened in Mid Staffs." $\mathrm{He}$ added that honouring recommendations this year to give staff a $1 \%$ increase in pay would have made it necessary to make 14000 nurses redundant.

But Burnham told the hustings event, which was attended by more than 200 doctors, patients, and health policy experts, that he could make the commitment: "We are spending a fortune on agencies. We are seeing vacant posts. There is excess at the top of some organisations. The government has removed unsocial hours payments. Reinstate the independent pay review body stood down by Jeremy Hunt."

Lamb warned of the need for a "trade off between pay and staff numbers" as the economy recovered and wage levels started to rise, which the NHS would have to keep up with.

Julia Reid, UKIP's deputy health spokeswoman, who worked in the NHS as a diabetes researcher, said that only UKIP's manifesto promises were fully funded, largely paid for by withdrawing from the European Union. She said, "We have seen people at the coalface have their salaries in real terms kept down. With our fully funded manifesto we will provide 8000 more doctors, 20000 more nurses, and 3000 more midwives. We will have GPs in all A\&E [hospital accident and emergency] departments."

The hustings event, held at the British Library in London, was organised by the BMA, the patient and carer organisation National Voices, the NHS Confederation, and the think tanks the King's Fund, Health Foundation, and Nuffield Trust. The BMJ was a media partner. Find out more at healthdebate.net.

Cite this as: BMJ 2015;350:h2164

๑) BMJ Publishing Group Ltd 2015 